Acta Universitatis Nicolai Copernici • Pedagogika XXXVII/1/2019

Nauki Humanistyczno-Społeczne • Zeszyt 447

DOI: http://dx.doi.org/10.12775/AUNC_PED.2019.009

\author{
Piotr Dubiel \\ Institute for Family Sciences \\ University of Opole \\ https://orcid.org/0000-0002-2111-8046

\section{EMOTIONAL ADDICTION FROM THE PERSPECTIVE OF GESTALT THERAPY}

\begin{abstract}
:
The article presents the conceptualisation of the phenomenon of emotional addiction, possible ways to make a diagnosis, and exposes certain methods of conducting therapeutic work with emotional addict patients from a perspective consistent with the approach of the Gestalt psychotherapy school.

Ke y word s: emotional addiction, psychotherapy, Gestalt therapy

\section{STRESZCZENIE:}

Artykuł przedstawia konceptualizację zjawiska uzależnienia emocjonalnego, możliwe sposoby dokonywania diagnozy, a także eksponuje pewne metody prowadzenia pracy terapeutycznej z pacjentami uzależnionymi emocjonalnie, w perspektywie zgodnej z podejściem szkoły psychoterapii Gestalt.

Słowa kluczowe: uzależnienie emocjonalne, psychoterapia, terapia Gestalt
\end{abstract}




\section{Introduction}

The purpose of the article is to present the perspective that the GeI stalt therapist could take in the phenomenon of emotional addiction. It will present selected elements of the Gestalt psychotherapy process, including conceptualisation of the phenomenon and an attempt to diagnose "addictive love" in line with the theory of psychopathology within this trend. Two approaches to diagnosis will be included: external diagnosis based on the description of symptoms, and internal diagnosis made on an ongoing basis during the session based on the distortions perceived by the therapist in the client's experience cycle. The basis for explaining the mechanism of emotional addiction will be an attempt to compare the emotional cycles of addicts with the disturbance cycle of organismic self-regulation described in Gestalt psychotherapy. Intervention methods that the Gestalt therapist could suggest to patients showing problems at boundary contact, typical for selected patterns of emotional dependence, will also be explored.

\section{General characteristics of Gestalt psychotherapy}

The Gestalt therapy created by Fritz Perls fits into the humanistic trend. Perls illustrated his ideas using the metaphor of Gestalt created by events extracted from the background by conscious attention. Closure of the figure is only possible by satisfying the need ${ }^{1}$. Perls also assumed that similar relationships to the process of perception exist in the formation of personality and the development of emotional life ${ }^{2}$. The goal of Gestalt therapy is to complete the figures from the past. Patients learn to identify and express emotions, including those which ceased a long time ago, which makes it easier to recall painful experiences that are completed using drama within the safe conditions of

${ }^{1}$ K. Drat-Ruszczak, Szkoty i kierunki psychoterapii. In: Podręcznik pomagania. Podstawy pomocy psychologicznej. Szkoły i kierunki psychoterapii, eds. K. DratRuszczak, E. Drążkowska-Zielińska, Warsaw 2005, p. 118.

2 M. Wolicki, Podstawy psychoterapii, Przemyśl-Sandomierz 2015, p. 67. 
therapy sessions ${ }^{3}$. Exercises to increase awareness of current feelings and behaviours help integrate conflicted personality aspects ${ }^{4}$.

In an original way, Gestalt merges and creates combinations of many different methods, verbal and non-verbal techniques, including: sensory awakening, work on energy, breathing, work with the body, expression of emotions, and even work on dreams. It puts emphasis on the awareness of current experience, prefers real contact and creative adaptation of the body to the environment, and realises internal mechanisms that force to repeat rigid, outdated behaviours. It enhances the processes of distorting the cycle of satisfying needs, exposing numerous fears, evasions and delusions. The intention is to attempt new, creative solutions ${ }^{5}$.

\section{Conceptualisation of an addictive love case in the Gestalt trend}

Gestalt recognises addiction as a well-established pattern of contact with the world. Addictive experience involves cutting off new stimuli and the desire to repeat the previous experience; a person replaces a figure formed in the past with something that in the current field is a stiffened Gestalt ${ }^{6}$. Such a continuous replacement of the primary sense of need with other feelings ${ }^{7}$ that will be accepted by the environment results in the creation of a stiff habit ${ }^{8}$. According to Gestalt psychopathology, emotional addiction can be considered as a constantly recurring distortion in cycles of contact with emotional need. The pro-

3 P. Oleś, K. Drat-Ruszczak, Koncepcje humanistyczne i psychologia pozytywna. In: Psychologia akademicka. Podręcznik, eds. J. Strelau, D. Doliński, Gdansk 2015, p. 688.

4 S. A. Rathus, Psychologia wspótczesna, Gdansk 2004, pp. 654-655.

5 S. Ginger, Gestalt. Sztuka kontaktu, Warsaw 2004, pp. 21-22.

6 P. Brownell, P. Schulthess, Zachowania związane z u̇̇ywaniem substancji. In: Psychoterapia Gestalt w praktyce klinicznej. Od psychopatologii do estetyki kontaktu, eds. G. Francesetti, M. Gecele, J. Roubal, Gdansk 2016, pp. 454-456.

7 P. Clarkson, J. Mackewn, Fritz Perls, Gdansk 2008, p. 112.

8 Ch. Sills, S. Fish, P. Lapworth, Pomoc psychologiczna w ujęciu Gestalt, Warsaw 1999, p. 76. 
cess of contacting with emotional need is presented in the form of an emotional cycle that is typical of a particular addiction pattern.

The emotional cycle of the "Love Addict" begins when they succumb to the allure of strength and flatteries of the "Avoiding Closeness" person. He or she begins to feel euphoria, believing that their fantasy is coming true. Gradually, as the person "Avoiding Closeness" moves away, trying to create a distance, they manifest more and more needs, encircle their partner and reject the reality of abandonment. The "Love Addict" tries to ignore the fact that their partner has already withdrawn from the relationship. This self-deception allows them to push away the unbearable torment of rejection and abandonment. Eventually, they begin to notice that their partner is leaving them and also withdraw themselves, but from this point they begin to obsessively think about how to force an "Avoiding Closeness" participant to return or how to get revenge on them. They can also repeat their cycle with the same partner or a new one'.

The cycle of those "Avoiding Closeness" is slightly different - they create a relationship with the "Love Addict" using some form of seduction to make the other person feel loved and special. At first they cling to their partner, but as a result of this adoration they begin to feel wrapped up in their needs and controlled. They feel anger and become critical. The feeling of being absorbed means that, through resentment and injury, they build a wall to distance themselves. They begin looking for intense experiences outside the relationship. Then, however, they feel guilty and, afraid of abandonment, return to bond with their former partner or another person; at this point, the entire emotional cycle begins again ${ }^{10}$.

A Gestalt therapist looking at the cycles of people addicted to "love" can see that each phase of the cycle has been distorted. When the sensation phase appears, the effects of old destructive relationships from the previous relationship, which condition the painful nature of current

9 P. Mellody, A. Wells-Miller, J.K. Miller, Toksyczna miłość i jak się z niej wyzwolić, Warsaw 2013, pp. 42-52.

10 Ibidem, pp. 71-74. 
sensations, already play a significant role ${ }^{11}$. The primary cycle disorder is in the contact and withdrawal phase. The addict does not experience contact with what would satisfy his or her natural needs. Therefore, staying in relationships or permanently establishing fleeting romances becomes a form of pseudo-contact that does not satisfy a healthy need but a substitute one. Moreover, the withdrawal phase is not being conducted correctly. The addict is either constantly flirting or unable to end the relationship. The rigid substitute figure is not dispersed. The experience of satisfying the need is not assimilated and the contact cycle does not end naturally, which means the person involved is constantly under pressure to repeat the disturbed cycle. Compulsive automatism perpetuates, and healthy self-regulation gives way to habitual regulation ${ }^{12}$.

It seems that, emotionally, addicts repeat rigid behaviours that prevent them from achieving satisfaction because their awareness does not allow them to isolate authentic needs from the background. They cannot focus on the new figure because it is absorbed by the old figure and the stiffened Gestalt that arises as a result of permanent premature closing of the cycle of primary need. Chronic deprivation of needs has led to the consolidation of the reaction of replacing natural actions with ones that distort contact. Such individuals were taught in childhood that they can receive love only "for something", meaning that their own natural impulse of striving to receive it has been destroyed and replaced with actions aimed at constantly meeting the expectations of others. This scheme is the only way they know of meeting their emotional needs.

\section{Diagnosis of emotional addiction in the Gestalt approach}

Diagnosis in Gestalt psychotherapy is a tool that allows the therapist to sensibly organise experiences in contact with the client. There are two types of diagnosis that help find a direction in a therapeutic relation-

11 J. Mellibruda, Z. Sobolewska-Mellibruda, Integracyjna psychoterapia uzależnień. Teoria i praktyka, Warsaw 2006, p. 65.

12 Ibidem, p. 65. 
ship, the first of which can be called an external diagnosis. It consists of comparing a specific phenomenon with its model and should be used to assist the contact process and support internal diagnosis. It gives a general overview of the therapeutic situation and provides the background for the therapist's work ${ }^{13}$.

The second type of diagnosis, referred to as internal diagnosis, is based on the observation of the flow of phenomena and emerges gradually in boundary contact as an internal component of the therapeutic process because it occurs constantly during the therapeutic session. Internal diagnosis is based on opinions, sensitising the senses, attention and requires the therapist to base his/her actions and understanding of the clinical situation on intuition, which is available thanks to training and experience, and allows appropriate interventions to be made ${ }^{14}$.

A Gestalt psychotherapist requires both types of diagnosis to direct the therapy properly. However, it seems that external diagnosis referring to the model of the phenomenon may cause some controversy in the case of emotional addiction because there is no officially recognised "model" of this phenomenon and it is necessary to refer to the description of other disorders, possibly leading to labelling of a person. Severe personality disorders, such as borderline disorders, are thought to cause this type of addiction ${ }^{15}$. According to a certain interpretative line, the form of addiction developing in co-dependent subjects resembles borderline personality disorders ${ }^{16}$.

Considering the assumptions above, it can be presumed that certain schemes and patterns of emotional addiction may coexist with specific types of personality disorders; further, people suffering from them will be more inclined to develop an adequate pattern of addictive "love". This assumption is probably justified because similarities can be demonstrated between the diagnostic criteria of certain types of personal-

13 J. Roubal, M. Gecele, G. Francesetti, Diagnoza w psychoterapii Gestalt. In: Psychoterapia Gestalt w praktyce klinicznej. Od psychopatologii do estetyki kontaktu, eds. G. Francesetti, M. Gecele, J. Roubal, Gdansk 2016, pp. 130-131.

14 Ibidem, pp. 102-104, 130-131.

15 H.P. Röhr, Uzależnienia. Przyczyny i terapia, Poznań 2013, p. 147.

16 C. Guerreschi, Nowe uzależnienia, Kraków 2010, pp. 187-190. 
ity disorders and significant features of emotionally addicted people. The table below presents an attempt to juxtapose schemes and patterns of emotional dependence with those personality disorders that seem to coincide with them.

Table 1.

Summary of schemes and patterns of "love" addiction with personality disorders ${ }^{17}$

\begin{tabular}{ll}
\hline \multicolumn{1}{c}{ Emotional addiction scheme and pattern } & Type and variety of personality disorder \\
\hline Love addict scheme & Borderline personality disorder - borderline \\
\hline Pattern of co-dependency (dependence) & $\begin{array}{l}\text { "Discouraged" variant - a combination of bor- } \\
\text { derline personality traits and dependent } \\
\text { personality traits }\end{array}$ \\
\hline Pattern of obsessive love & "Impulsive" variant - a combination of bor- \\
& $\begin{array}{l}\text { derline personality traits with histrionic } \\
\text { personality traits }\end{array}$ \\
\hline Scheme of one avoiding closeness & Narcissistic personality disorder \\
\hline Pattern of infatuation and fantasising & "Compensatory" variant - a combination \\
& of narcissistic personality traits and avoiding \\
personality traits
\end{tabular}

It seems that the basis for the development of the co-dependency pattern may be the "discouraged" variant of borderline personality disorder. An individual exhibiting such a disorder adopts a strategy of attachment full of submission towards the selected person whom he or she constantly clings to. To strengthen this relationship, they will fuse their own identity with that of the partner ${ }^{18}$. The pattern of obsessive love can also develop in people with the "impulsive" variant as these individuals form unstable relationships and tend to constantly chase

17 Own study based on: T. Millon, R. Davis, Zaburzenia osobowości we wspótczesnym świecie, Warsaw 2005.

18 Ibidem, pp. 561-562. 
romantic fusions with other people. If they are not always at the centre of the other's attention, they become more and more seductive, impulsive, capricious, irresponsible and restless, afraid of losing their partner $^{19}$. It can be assumed that the pattern of infatuation and fantasising is shown by people exhibiting the "compensatory" variant. They overcome a deep sense of inferiority and extremely low self-esteem by creating an illusion of superiority and uniqueness. They also indulge in grand fantasies of their own glory and success. Fearing evaluation, they will delay taking any action in the real world, preferring to play a leading role in the theatre of imagination ${ }^{20}$. In contrast, the pattern of ambivalent love seems to appear frequently in individuals with the "seductive" variant. Such people will charm and deceive yet remain reluctant when it comes to real closeness. Rather, they choose to flirt with several people at the same time. It may seem that they desire warmth in a close relationship, but when they find it they feel anxiety and dissatisfaction. Having won someone, these individuals will quickly begin to underestimate themselves and must continue to play elsewhere. Such a person is considered attractive, but their relationships are always superficial ${ }^{21}$.

The described personality disorders can serve as a reference for the therapist, functioning as the basis for external diagnosis which merely supports internal diagnosis, where the therapist pays attention to the overall behaviour of the patient. Perls, Hefferline and Goodman suggest diagnosing not the person but the process, and then determining how it interferes with one's current experience: whether it is confluence, introjection, projection, retroflexion, egotism or desensitisation. The typology presented can be helpful in describing the structure of a single behaviour rather than determining the whole picture of the patient ${ }^{22}$.

According to the recommendations described, an attempt will be made to make a simplified form of emotional addiction diagnosis. The

19 Ibidem, pp. 561-576.

20 Ibidem, pp. 375-376.

21 Ibidem, pp. 374-375.

22 P. Clarkson, J. Mackewn, op. cit., p. 138. 
main goal will be to determine what mechanisms of contact avoidance are used and to indicate the stages of the cycle in which addicts make them. It can be assumed that - depending on the pattern by which they implement their addiction in action - they will show a greater tendency to distort the spontaneity of the cycle in other stages, using typical mechanisms of contact avoidance. Below is a graphic comparison of the self-regulation sequences developed by Zinker and Sills, Fish and Lapworth, considering the distortion points typical for particular emotional addiction patterns.

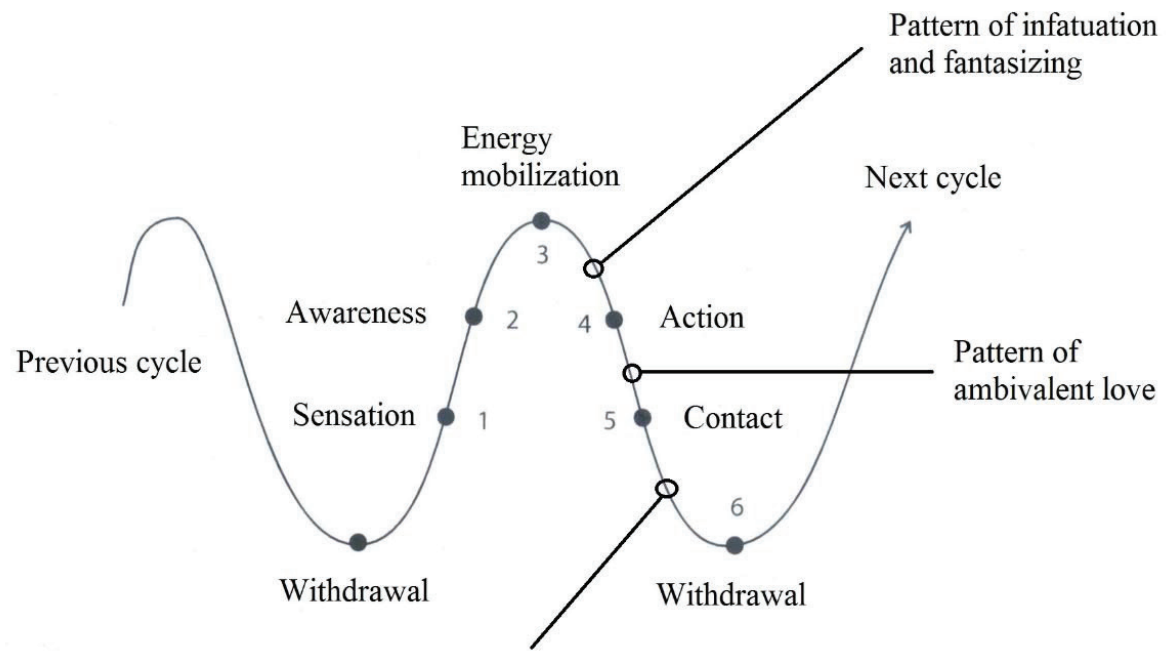

Pattern of obsessive love

Pattern of codependency

Figure 1. Zinker's cycle: places of distortion typical of various addiction patterns ${ }^{23}$

23 Own study based on: M. Paruzel-Czachura, Między psychologia, psychoterapia i filozofia praktyczną. Poszukiwanie autentycznego życia w nurcie Gestalt, Sopot 2015, p. 125. 
According to the contact cycle created by Zinker, the disturbance between the energy mobilisation stage and the stage of action is typical for people who are unable to act in accordance with their impulses. Despite being mobilised, they are unable to use their energy for actions which will fulfil their desires; they dissipate the accumulated energy for fear of failure, ridicule, disappointment, or overt disapproval from others $^{24}$. It can therefore be assumed that the distortion appearing at this stage of the cycle may be characteristic for people who follow the pattern of infatuation and fantasising.

The distortion of the cycle that occurs between the action stage and the contact stage makes the person unable to assimilate dispersed feelings. He or she is not able to act vigorously, single-pointed - they're constantly distracted. They feel a lack of contact with their environment and experience the shallowness of internal life, which they might feel physically as an emptiness in the chest or stomach. They try to compensate for their feeling of inner emptiness with excessive sexual activity, overeating or drug use ${ }^{25}$. It seems that the inflexion at this stage of the experience cycle may be typical for people who implement the pattern of ambivalent love in their relationship with their partner.

A person who disrupts the rhythm of contact and withdrawal is incapable of giving up when the experience culminates and he or she stays with it even after reaching the optimum. They have trouble dosing the contact and tend to not hear messages from others. The reason for their intense fear of loneliness and inactivity is the hidden fear of total stillness associated with death, which is why they are characterised by constant mobilisation ${ }^{26}$. It can be assumed that the inflexion at this stage of the cycle is characteristic for patients who follow the pattern of co-dependency and the pattern of obsessive love.

Some differences in the course of individual stages are evident in the cycle model created by Sills, Fish and Lapworth, which contains seven distinct stages. According to this cycle model a disorder can oc-

\footnotetext{
24 J. Zinker, Proces twórczy w terapii Gestalt, Warsaw 1991, pp. 95-97.

25 Ibidem, p. 98.

26 Ibidem, pp. 100-101.
} 
cur during the assessment and planning stage, at which point a person is unable to convert mobilised energy into effective action and finds it difficult to make decisions ${ }^{27}$. This kind of distortion of contact spontaneity can therefore be attributed to those who implement their emotional addiction through a pattern of avoiding intimacy, and their addictive actions taken towards a partner in a relationship are accurately described by a pattern of infatuation and fantasising.

Another distortion is revealed at the transition between the stage of action and the stage of contact, manifesting itself in excessive, continuous activity. Such people tend to constantly repeat their experiences. However, they fail to come into full contact with other people and men who form inflexion at this stage are sometimes recognised as having "Casanova syndrome" because one sexual prey follows the other, thus allowing them to constantly avoid truly intimate contact with a partner $^{28}$. The distortion in the spontaneity of the cycle that appears at this point may characterise patients who behave in accordance with the pattern of ambivalent love in their close relationships.

Individuals that disturb the contact cycle within the stages of assimilation and closure, and withdrawal, have difficulty achieving satisfaction, are very afraid of staying alone, fear abandonment, and will therefore desperately defend themselves before ending the relationship ${ }^{29}$. They don't want to experience the suffering of having to say goodbye and as a result they cling to their partner ${ }^{30}$. It seems that people who distort the spontaneity of contact in this way realise the pattern of obsessive love or the pattern of co-dependency in their relationships.

27 Ch. Sills, S. Fish, P. Lapworth, op. cit., p. 59.

28 Ibidem, p. 60.

29 Ch. Sills, S. Fish, P. Lapworth, op. cit., p. 60.

30 W. Eichelberger, Pomóż sobie. Daj światu odetchnać, Warsaw 1995, pp. 81-82. 
Pattern of obsessive love Pattern of infatuation and fantasizing Pattern of codependency

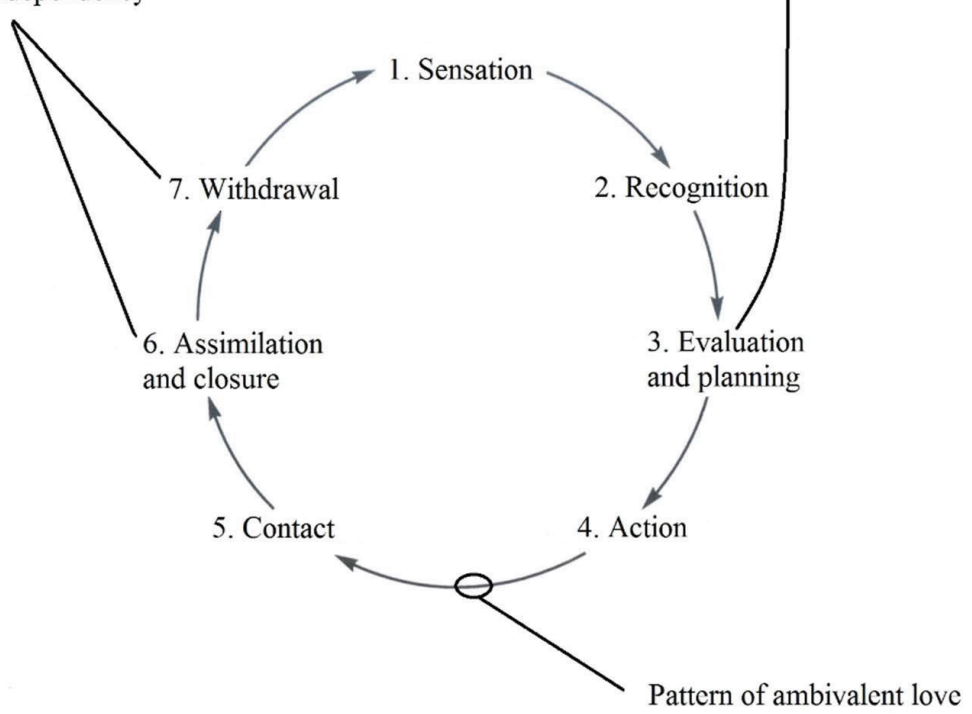

Figure 2. The cycle produced by Sills et al.: distortion places typical for various addiction patterns ${ }^{31}$.

Specific emotional addiction patterns appear to have determined combinations of contact inflexion. Clients who follow the pattern of co-dependency might use mechanisms of confluence and proflexion, while those who follow the pattern of obsessive love will avoid contact by means of confluence or projection. Moreover, those individuals whose behaviour is described by the "Avoiding Closeness" scheme retroflex regardless of the pattern and show excessive egotism. Despite using the same methods of avoiding contact, the effects of their behaviour are different because disturbances occur at other stages of the cycle. A fantasising person creates cycle distortion before it reaches the stage of action. He or she only dreams in their imagination. Alternatively, an addict who creates unstable relationships cannot attain full con-

31 Own study based on: M. Paruzel-Czachura, op. cit., p. 126. 
tact with the partner and the initiated relationship breaks down. The mechanisms typical for a given addiction pattern are presented in the table below.

Table 2.

Contact inflexions typical for particular patterns of "love" addiction ${ }^{32}$

EMOTIONAL ADDICTION PATTERN

TYPE OF CONTACT INFLEXION

\begin{tabular}{|c|c|}
\hline \multicolumn{2}{|c|}{ Love Addict scheme } \\
\hline Co-dependency pattern & Confluence, proflexion \\
\hline Obsessive love & Confluence interchangeably with projection \\
\hline \multicolumn{2}{|c|}{ Avoiding Closeness scheme } \\
\hline Pattern of infatuation and fantasising & Egotism, retroflexion \\
\hline Pattern of ambivalent love & \\
\hline
\end{tabular}

Since none of the contact disturbances occur in isolation from the others, the above assumptions should be treated with caution. Perls emphasised that even when a person is prone to one type of imbalance, he or she also experiences a combination of other disturbances ${ }^{33}$. However, simplification of this type can be allowed to indicate mechanisms dominating in the behaviour of people manifesting a specific addiction pattern.

\section{Gestalt therapy interventions against selected addiction patterns}

Therapeutic work with the emotionally addicted can be particularly difficult. Given the variety of patterns within this addiction, the therapist must make an internal diagnosis on an ongoing basis so as not to make a mistake in assessing the type of contact spontaneity distortions exhibited by the patient. Each pattern requires slightly different reac-

\footnotetext{
32 Own study.

33 P. Clarkson, J. Mackewn, op. cit., p. 123.
} 
tions. The biggest differences are between the patterns of obsessive love and infatuation-fantasising. Discussing the methods used in these cases allows us to highlight the divergence between different directions of therapeutic work.

\section{Working with a client who shows a pattern of infatuation and fantasising}

An addict realising the pattern of infatuation and fantasising in his or her relationships does not intervene in a creative, independent way. Indeed, he or she finds it extremely difficult to take their place in professional and private life; such individuals get the impression that they do not belong to this world, and consequently they escape into dreams of how everything could look ${ }^{34}$. While working with such a person the therapist will pay attention to their withdrawn posture, as if they are constantly ready to dodge the blow. Using a male example, the therapist may ask the patient to say what he feels when sitting in such a way ${ }^{35}$. The patient may respond: 'My body is in a position as if I was always on alert'. Hearing this formulation, the therapist will instruct the patient to replace it with another - 'I keep myself in a position as if I was always on alert' - and will ask him to pay attention to how he feels when he says these words. When the patient becomes more aware, the therapist may ask him to make another statement - 'I keep myself ready in case you...' - and to finish the sentence in the most appropriate way. The patient's answer could be: 'I keep myself ready because you can hurt me'. Then, the therapist may suggest looking for statements that would reflect this condition, e.g. 'I can't reveal my true feelings'. This exercise will initiate work on unfinished issues when the patient remembers the old need to hide his feelings from his father, and on his childhood experiences when he was constantly on his guard against the father's anger and negative judgement ${ }^{36}$.

34 B. Wardetzki, Policzek dla duszy. Jak możemy lepiej poradzić sobie z urazami i odrzuceniem, Kielce 2002, p. 29.

35 J.I. Kepner, Ciało $w$ procesie psychoterapii, Warsaw 1991, pp. 28-32, 167-174.

36 Ibidem, p. 141. 
The therapist may then suggest that the patient should take care of the body structure to enable him to know his inner opposites by exaggerating the demonstrated behaviour and to play its opposite while constantly examining the feelings associated with one and the other process. The therapist will ask the patient to describe their impressions of the experiment, and they may highlight their anxiety. The therapist will now try to learn with the client the nature of this fear. They may ask the patient to consider any points during their youth where they had to back down. The patient may then recall how in childhood he had repeatedly witnessed situations in which his father furiously attacked his mother. Faced with the need to choose between the desire to defend her and the fear of violence from an angry father, he often withdrew into the corner of the room, behind a piece of furniture, observing the situation ${ }^{37}$.

The next stage will consist of work on the conflict between the fragments of "I". To this end, the therapist can arrange a dialogue between two parts of the "I" or between "I" and the internalised characters. They may suggest working with an empty chair; during the work, the client will first experience fear and then express anger towards his father. When the tide of anger passes, sadness will arise, which is followed by regret that the father has let them down. He will begin to accept the fact that he couldn't force his father to be a good father and relieve him of his obligation to appreciate his son. Exploring relationships with a mother might reveal an ambivalent attitude towards her: on the one hand, idealisation and desire to save her, and on the other, realisation of reversed roles in the mother-son relationship and the desire for the mother to take care of him instead of expecting protection from him. At work with an empty chair the patient can express his regret to the mother and then give up the mission of protection. He will cease to idealise her. Ideally, he will also accept that she did not provide him with sufficient care, attention and security ${ }^{38}$.

37 Ibidem, pp. 72-73, 177-188.

38 Z. Sobolewska-Mellibruda, Psychoterapia dorostych dzieci alkoholików. Strategie, procedury i opisy przypadków pracy psychoterapeutycznej, Warsaw 2011, pp. 106-119. 
Once the client regains his disturbed balance by tolerating and accepting alienated aspects of the ego, he can begin to develop and practise new ways of interacting with the environment. He should learn first in relation with the therapist - to be both "soft" and "separated". He must then be able to consciously express these attitudes in his relationships with other people. In this way, he will increase his flexibility and begin to distinguish between an environment that accepts feelings and displaying them from one that does not favour them. He will work on a more optimal adaptation to life. The goal of therapeutic work will be to further increase the flexibility and permeability of its borders, as well as to ensure the client is aware of the needs in terms of space and the methods he habitually uses to defend it, also highlighting the consequences it causes in close interpersonal contact ${ }^{39}$.

\section{Working with a client who manifests pattern of obsessive love}

People who implement obsessive love in their interactions with their partner concentrate their whole lives around other people's matters. Their problem probably lies in the fact that when detached from contact, they have a poor sense of their physical nature and cannot anchor in it. Without having a place in their own body to which they could take refuge they maintain a state of "merging" with others, which provides them with a sense of their own "I". They lack an explicit and clear sense of themselves, except in the moments when other people are the ones who define them in some way ${ }^{40}$.

The therapist - while working with a man who exhibits the pattern of obsessive love - may notice that this patient often experiences active resistance to refraining from constantly talking about the object of his "feelings". They can then suggest that the reason the client requires therapy is that he could see how he would feel thinking and speaking a little less about that person. When the patient agrees, the therapist

39 J.I. Kepner, op. cit., pp. 74-75, 214-215.

40 Ibidem, pp. 227-229. 
will offer him some experiments which will help to prevent the habitual actions. First, they will encourage the client to interrupt his speech stream from time to time and ask him if the way he speaks is directly related to his body's needs. This will allow the emotional addict to finally realise that his body is constantly undergoing physical overload; if he wants to meet his needs, he should finally 'let himself rest'. The therapist, together with the client, will begin looking for appropriate ways for the patient to rest a little during each session. This stage of the work will be devoted to teaching an obsessive individual how he can gradually detach from an excessive, compulsive focus on his partner ${ }^{41}$.

Initially, the patient needs strong support from the therapist to allow himself to withdraw from his activity and involvement in the relationship with the partner. Slowly, he begins to recognise the body's need for withdrawal and to regain contact with himself, but at this point a new problem may emerge in relation to the fact that the client will not be able to find any inner space in which he can shelter when he is not engaged in an emotional relationship. Common therapeutic work will now be focused predominantly on developing the patient's body sensitivity so that he has a place where he can stay without being involved in a relationship. This can be achieved through touch and breath exercises. Gradually, the client might feel his body more clearly and may start to discover alternative places where he can place himself $f^{42}$.

In parallel with the recovery of the internal space of the body, the patient's tendency to focus too much on the other can decrease; this increases the motivation to discover their inner being, with whom they have lost contact when living a partner-only life. Body-oriented work can become the beginning of a process in which the client learns to slow down the pace of life, to breathe properly and to withdraw from life activities at the right time. This stage serves to regain contact with one's self by targeting the process of detaching from contact and is the first step in overcoming difficulties in the field of withdrawal skills ${ }^{43}$.

\footnotetext{
41 Ibidem, pp. 231-232.

42 Ibidem, p. 233.

43 Ibidem, p. 233.
} 
With the ability to slow down the pace of life, recover the bodily aspect of themselves and give up constant activity directed at the other person, the client can come into contact with feelings related to the withdrawal process: a sense of emptiness, loneliness and abandonment. When he achieves better contact with his body, he may feel emptiness and nothingness with increasing intensity. The therapist will then propose to the patient an experiment with repeating sentences: 'I'm empty inside. I'm leaky and totally unfilled'. These types of sensations may initially cause severe anxiety. For most of his life, the client has been pushing his sense of vacuum outside of his consciousness via an excessive focus on the partner. In this scenario, he is only able to confront these feelings and tolerate them thanks to the bond and trust in the therapist, as well as regaining contact with the body. Together with the patient the therapist will try to observe what in the feeling of emptiness raises this fear. The patient can then state: 'This confirms my belief that I am nothing indeed, that I have no value ${ }^{24}$.

The client should stay with this feeling for some time to bring back memories and realise the earlier situations in which it has appeared. The therapist may ask the patient to assess this situation empirically, uttering a sentence as if directed to his parents: 'You gave me so little that I feel emptiness through you now'. The patient may not want to comply with this request, arguing that this could not be true. The therapist should explain that the truth of this statement can be verified empirically. Following this command may lead to contact with the feeling of regret and initiate a new stage of work. Each time the client manages to withdraw from his activity towards the partner and a bodily sense of emptiness appears, the therapist will offer him the opportunity to express it "as if" he were a child having to respond verbally to the situation that had once existed at home. The therapist will ask the patient to try to say the following sentences: 'It's so empty in this family' or 'For me, something is missing here'. When a client in the same situation experiences internal pressure to engage more intensively in a relationship with a partner, the therapist will suggest repeating the statement:

${ }^{44}$ Ibidem, p. 234. 
'I can never stop seeking interest of you both'. Furthermore, when the client experiences the feeling of loneliness, the therapist will ask him to experiment with the statement: 'You are leaving me all alone, without any support'. Gradually, the patient may begin to remind himself that his family home was cold, his parents kept their distance from each other and could not give love, and he himself did not have close, cordial relations with them ${ }^{45}$.

This experiment could help the client regret his emotionless, empty and lonely childhood. Consequently, the client may realise that the experience he perceived as "his" emptiness and treated as an individual feature was the effect of the influence that other people had on him during childhood. Now, with the ability to fully experience his own feelings, he may be able to mourn for the things he has lost and which he will never have the chance to regain. After this stage of discovering sadness and a sense of loss as a recurring, unfinished issue, there will be a period of acceptance for the feelings of anger the patient had towards his family ${ }^{46}$. These emotions could be experienced and expressed at work with an empty chair. Closing an unfinished issue could free the client from the stiffened Gestalt and help end the obsessive relationship with his partner. Then, the patient will be able to open himself to experiments with new behaviours that, when implemented, would allow him to keep his identity in a close relationship in the future and therefore not become addicted emotionally again. For individuals prone to strong confluence with their partner, one could recommend Fritz Perls' "Prayer", which should become an important key in establishing proper relationships with other people.

\section{Summary}

The purpose of this article was to present selected elements of the Gestalt therapy process in relation to the phenomenon of emotional addiction. The conceptualisation of "love" addiction corresponding to the

45 Ibidem, pp. 235-236.

46 Ibidem, p. 237. 
Gestalt psychopathology theory has been achieved by comparing their emotional cycles with the sequence of disturbed self-regulation. When discussing the diagnosis used in the Gestalt trend, two types were considered: external diagnosis based on the description of symptoms and internal diagnosis consisting of careful observation of how the client creates relationships and perceptions of distortion types of contact spontaneity being exhibited by the client, which is accomplished during a session. Proposals for the use of both types of diagnosis to recognise an addictive "love" case have been presented. The external diagnosis was based on certain types of personality disorders whose diagnostic criteria seem to closely match specific patterns of emotional addiction, whereas internal diagnosis was accomplished in a somewhat simplified way, emphasising only those contact inflexions that seem to be most characteristic for patients implementing a given addiction pattern. This treatment enabled an indication of possible directions of therapeutic work in which - with skilful application of appropriate techniques - the therapist could arrange experimental situations adequate to the client's problems.

\section{References}

Brownell, P., Schulthess, P. „Zachowania związane z używaniem substancji". In: Psychoterapia Gestalt w praktyce klinicznej. Od psychopatologii do estetyki, eds. Gianni Francesetti, Michela Gecele, Jan Roubal, 445-472. Gdańsk: Harmonia Uniwersalis, 2016.

Clarkson, P., Mackewn, J. Fritz Perls. Gdańsk: Gdańskie Wydawnictwo Psychologiczne, 2008.

Drat-Ruszczak, K. „Szkoły i kierunki psychoterapii”. In: Podręcznik pomagania. Podstawy pomocy psychologicznej. Szkoły i kierunki psychoterapii, eds. Krystyna Drat-Ruszczak, Ewa Drążkowska-Zielińska, 91-136. Warszawa: Wydawnictwo Szkoły Wyższej Psychologii Społecznej „Academica”, 2005.

Eichelberger, W. Pomóź sobie. Daj światu odetchnąć. Warszawa: Agencja Wydawnicza „Tu”, 1995. 
Ginger, S. Gestalt. Sztuka kontaktu. Warszawa: Wydawnictwo Jacek Senatorski \& Co., 2004.

Guerreschi, C. Nowe uzależnienia. Kraków: Wydawnictwo „Salwator”, 2010.

Kepner, J.I. Ciało w procesie psychoterapii Gestalt. Warszawa: „Pusty Obłok”, 1991.

Mellibruda, J, Sobolewska-Mellibruda, Z. Integracyjna psychoterapia uzależnień. Teoria i praktyka. Warszawa: Instytut Psychologii Zdrowia, 2006.

Mellody, P., Wells-Miller A., Miller, Keith J., Toksyczna miłość i jak się z niej wyzwolić. Warszawa: Wydawnictwo Czarna Owca, 2013.

Millon T., Davis R. Zaburzenia osobowości we współczesnym świecie. Warszawa: Instytut Psychologii Zdrowia. Polskie Towarzystwo Psychologiczne, 2005.

Oleś P., Drat-Ruszczak K. „Koncepcje humanistyczne i psychologia pozytywna". In: Psychologia akademicka. Podręcznik, eds. Jan Strelau, Dariusz Doliński, 683-697. Gdańsk: Gdańskie Wydawnictwo Psychologiczne, 2015.

Paruzel-Czachura, M. Między psychologia, psychoterapia i filozofia praktyczna. Poszukiwanie autentycznego życia w nurcie Gestalt. Sopot: Gdańskie Wydawnictwo Psychologiczne, 2015.

Rathus, S.A. Psychologia współczesna. Gdańsk: Gdańskie Wydawnictwo Psychologiczne, 2004.

Roubal J., Gecele M., Francesetti G., „Diagnoza w psychoterapii Gestalt”. In: Psychoterapia Gestalt w praktyce klinicznej. Od psychopatologii do estetyki kontaktu, eds. Gianni Francesetti, Michela Gecele, Jan Roubal, 101-133. Gdańsk: Harmonia Uniwersalis, 2016.

Röhr, Heinz P. Uzależnienia. Przyczyny i terapia. Poznań: Wydawnictwo Polskiej Prowincji Dominikanów „W drodze”, 2013.

Sills Ch., Fish S., Lapworth P. Pomoc psychologiczna w ujęciu Gestalt. Warszawa: Instytut Psychologii Zdrowia Polskiego Towarzystwa Psychologicznego, 1999.

Sobolewska-Mellibruda, Z. Psychoterapia dorostych dzieci alkoholików. Strategie, procedury i opisy przypadków pracy psychoterapeutycznej. Warszawa: Instytut Psychologii Zdrowia Polskiego Towarzystwa Psychologicznego, 2011.

Wardetzki, B. Policzek dla duszy. Jak możemy lepiej poradzić sobie z urazami i odrzuceniem. Kielce: Wydawnictwo „Jedność”, 2002. 
Wolicki, M. Podstawy psychoterapii. Przemyśl-Sandomierz: Wydawnictwo Diecezjalne i Drukarnia w Sandomierzu, 2015.

Zinker, J. Proces twórczy w terapii Gestalt. Warszawa: Jacek Senatorski \& Agencja Wydawnicza, 1991. 